\title{
Establishing a Common Framework for Strategic Communications in Ecosystem-Based Management and the Natural Sciences
}

\author{
Matthew C. Harwell, Jeannine L. Molleda, Chloe A. Jackson, \\ and Leah Sharpe
}

\begin{abstract}
There is a need for a generalized framework and guidance for developing strategic communication efforts for interdisciplinary practitioners of ecosystembased management to ensure engagement and communication efforts focus on effective science-society dialogue. Too often, however, developing and implementing communication strategies is viewed as separate from the research and not undertaken until the research is complete. Developing a strategic communication plan involves outlining and articulating a project's goals and objectives, identifying communication goals, defining messages, audiences, and vehicles, characterizing the different types of communication flow paths (both internal and external), and developing clear metrics that will allow for evaluating the success of the communication plan. A strategic communication matrix provides an organizational and operational structure for implementing a strategic communication plan. Here, we offer specific guidance tailored to scientists, stakeholders, and decision makers for developing strategic communication efforts. This tailored framework is then examined through a case study application in the field of ecosystem-based management.
\end{abstract}

\section{Lessons Learned}

- There is a lack of peer-reviewed literature on the development and implementation of strategic communications (focusing on message, audience, vehicle) with the ecosystem-based management and natural sciences literature.

- Efforts to develop and implement strategic communication plans are more effective when there is holistic buy-in from organizations.

M. C. Harwell ( $ه)$ J. L. Molleda · L. Sharpe

Gulf Ecosystem Measurement and Modeling Division, U.S. EPA, Gulf Breeze, FL, USA

e-mail: Harwell.matthew@epa.gov; jmolleda@pgrenewables.com; Sharpe.leah@epa.gov

C. A. Jackson

ORISE Research Participant, Pacific Ecological Systems Division, Newport, OR, USA

e-mail: Jackson.chloe@epa.gov 
- It is key to have a proactive communication effort from the beginning of a scientific effort, and it is just as important to develop evaluation and feedback methods to understand the effectiveness of the specific messages presented to particular audiences using the chosen communication vehicles.

- An organized framework for strategic communication moves general science communication from a tactical "list of tasks" to a more comprehensive strategy to communicate the relevance of the science.

- A strategic communication matrix can be used to effectively organize messages for specific audiences using specific vehicles to address overall communication goals for a given effort.

\section{Needs to Advance EBM}

- There is a need to implement strategic communication frameworks, ideally from the beginning of a project life-cycle, to advance both principles of EBM and casestudy applications of EBM into future studies.

- There is a need to study previous EBM communication efforts in both the peerreviewed and grey literature to determine their effectiveness and help improve communication efforts moving forward.

- Documentation of strategic communication efforts can inform assessing the effectiveness and success of communication and be used to help inform future communication efforts.

\section{Introduction}

Over the last few decades, the use of strategic communication has become increasingly prominent and valued across many disciplines, including Ecosystem-Based Management (EBM). Strategic communication is a three-element process that involves specific efforts to get the proper message delivered using the correct form (vehicle) of communication, to the intended audience, at the appropriate time (Braus 2009). A strategic communication approach is a useful tool to tackle sensitive topics, define and prioritize target groups, and standardize communication processes (Ekebom et al. 2008). In addition to communicating information, principles of strategic communication have been used to achieve a variety of goals ranging from persuasion (Halloran 2007) to coordination (Murphy 2008) to behavioral changes (Cabanero-Verzosa and Elaheebocus 2008; Mortenius 2014).

A strategic communication approach asks decision makers and stakeholders to think holistically about their communication efforts, looking beyond information sharing to think purposefully about what they want to achieve by sharing information. For practitioners of EBM, the importance of a meaningful science-policy dialogue is paramount to the effectiveness of using an EBM approach to bring science into the discussion and decision-making process for socio-ecological decisions (e.g., Long et al. 2015; Mattheiß et al. 2018; O’Higgins et al. 2020).

A recent case study analysis of multiple EBM efforts by Mattheiß et al. (2018) concluded that better communication strategies are needed to improve effectiveness 
of EBM efforts. In this chapter, we demonstrate why this approach is worth taking and articulate a generalizable framework for scientists, decision makers, stakeholders, and the larger EBM community of practitioners. We argue that it is not just the field of science that should embrace a strategic communication philosophy, but the full suite of EBM practitioners, including decision makers and stakeholders, and that this approach should not begin once results are ready for dissemination or publication but be incorporated throughout the decision process.

Ecosystem-based managers who develop conservation plans, projects, and policies work to understand people's perceptions while promoting habitat conservation (Goldberg et al. 2016). A number of chapters in this text acknowledge the important role of strong communication to maximize effectiveness of EBM efforts (e.g., Myer and Johnston 2020; Williams and Hoffman 2020). Long et al.'s (2015) analysis of core principles of EBM recognise the importance of communications as part of EBM implementation (Long et al. 2015).

Stakeholder engagement and involvement, a focused effort on bringing the appropriate groups of people together to discuss, and engage, on aspects of a given decision, is recognized as another core principle in EBM (Long et al. 2015). The goals of a given communication, or dialog, effort often go beyond simple transfer of information. For example, the Uganda Nutrition and Early Childhood Development Project identified behavior change as their ultimate goal and incorporated two-way dialog with stakeholders to ensure project objectives aligned with needs and demands of their project's beneficiaries (Cabanero-Verzosa and Elaheebocus 2008). By understanding beneficiaries' attitudes, beliefs, and practices, they improved the health and nutritional status of their clients, improved stakeholders' knowledge and practices, increased a demand for community health services and schooling, and enhanced local and social capacity within the community (Cabanero-Verzosa and Elaheebocus 2008). Including audiences' attitudes and perceptions in management considerations increases the likelihood of success (Goldberg et al. 2016).

A strategic approach to communication recognizes that true communication is a two-way process and that it is important to understand what the identified audiences are looking to get out of these interactions (USFWS 2016). A strategic communication program moves beyond limitations of most common communication models (e.g., "one size fits all," "presenting everything and letting the audience decide what is important," or "thinking that communication ends once information has been presented") and specifically focuses on building a communication framework composed of three interlinked pillars-message, audience, and vehicle-resting on the common foundation of clearly articulated communication goals. In addition to serving as an organizational framework, the physical structure of a strategic communication plan shows an audience where they fit into the larger picture. From an EBM context, this aligns with the core principle of "recognise coupled socialecological system" (Long et al. 2015). Additionally, a robust strategic communication plan incorporates context-specific metrics for determining communication effectiveness and success. As described later, metrics can focus on one or more communication elements to inform whether the communication goals were met. As a 
whole, these important elements are relevant to applied science, stakeholder engagement, and decision making.

The National Academies of Sciences, Engineering, and Medicine (NASEM) find that it is important to communicate science effectively because people need to be able to integrate accurate scientific information into their personal values and life decisions (NASEM 2017). Traditional science communication approaches often assume that the main goal is to address the deficit of scientific understanding among non-scientists (Groffman et al. 2010; NASEM 2017). This approach assumes that once an audience is educated on the topic, the work of communicators is done (Kellstedt et al. 2008; Bubela et al. 2009; Groffman et al. 2010; NASEM 2017). However, studies show that while audiences do not lack the knowledge to understand, they interpret and use information they receive in different ways (e.g., Hansen et al. 2003). The difference between a science communication deficit model and a strategic communication model is that the latter is "a purposeful use of communication by an organization to fulfil its mission" (Hallahan et al. 2007) that does not make inherent assumptions about the audience's level of knowledge about a topic and encompasses goals beyond information transfer.

Liang et al. (2018) propose the term "Strategic Environmental Communication" (SEC), which combines the concepts of environmental communication, strategic communication, and persuasion research. Practitioners and scientists can use SEC to design strategic environmental campaigns using well-designed messages and science-based strategies (Liang et al. 2018). Strategic environmental communication takes the concept of strategic communication and applies it to increase the effectiveness of environmental campaigns used to promote pro-environmental attitudes, behaviors, and investments (Liang et al. 2018). Whether focusing solely on strategic communication, or adopting the concept of SEC, practitioners and scientists can benefit from a strategic approach to communication research.

Scientific results are not always available or accessible to the public and decision makers and questions addressed by scientists do not always speak directly to stakeholder concerns. We argue that strategic communication is a way to help bridge the gap between the two (de Bruin and Bostrom 2012; Winterfeldt 2012; Jones et al. 2013). By taking a strategic communication approach throughout the lifecycle of a research project, scientists can tailor their approach to respond to stakeholder priorities or develop buy-in and participation from stakeholders and collaborators, making communication a well thought-out, long-term process rather than a reactive exercise or one constructed after the project's completion (Odugbemi and Mozammel 2005). This helps ensure that the science meets the need of management within communities, and vice versa (DeLauer et al. 2012). We argue that the use of a strategic communication approach thus can be useful in efforts to achieve another core EBM principle, "decisions reflect societal choice" (Long et al. 2015), or at the minimum, a societal-choice-informed decision adequately considers the science elements involved. By studying and researching strategic science communication, one can better understand how effective communication might influence audience interpretations and reactions, as well as how audience responses might influence next steps in science programs and management decisions (Barker 2006; Jones et al. 
2013). Through an analysis of strategic science communication research to date, we have developed a generalizable framework that can be applied across a range of scientific disciplines.

There is wide consensus that natural sciences would benefit from putting more effort into strategic communication efforts (Barker 2006; Hobbs 2006; Groffman et al. 2010), but most natural scientists, decision makers, and stakeholders have not been trained in strategic communication, and traditional science communication training has typically focused on information transfer clarity after the research has been completed (e.g., Turbek et al. 2016). In order to present a framework based on analysis of the available literature and tailored guidance for facilitating a strategic communications approach for natural scientists, decision makers, and stakeholders, this chapter is organized in the following manner. First, we conduct a literature review on strategic communication in the natural sciences. Second, we discuss the eight steps of developing a generalized framework for strategic communication in the natural sciences. Third, we discuss how to develop, implement, and track a strategic communication plan through a hypothetical ecosystem services case study.

\section{Literature Review}

A natural sciences literature review was conducted to characterize published efforts to organize, develop, and utilize strategic communication. The search focused on examples of strategic communication within the natural sciences to identify examples that included a clearly articulated strategic communication plan or framework. The primary search was on peer-reviewed literature related to the natural sciences. Additionally, we examined other science disciplines (e.g., health, political, and social sciences), non-science examples (business, military, and education), and communications field examples (public relations, technical/social media, and customer service). Utilizing multiple literature search engines, including Web of Science, Google Scholar, and Publish or Perish, the term "strategic communication" was searched by itself, as well with the following terms: "natural resources management," "ecosystem restoration," "adaptive management," "structured decision-making," "habitat conservation," and "ecosystem based management." While "strategic communication" approaches were not explicitly identified in many EBM examples, a large EBM case study analysis by Mattheiß et al. (2018) concluded that "the better the communication strategy the likelier the demand for scientific knowledge from the social system."

Potential articles were identified and subsequently filtered by title and abstract to determine whether papers were relevant with applicable information looking for title key words such as "communication" and "strategic" or articulation of strategic communication elements in the abstract. All remaining articles were then examined for information applicable to identifying elements of strategic communication yielding articles for further, in-depth analysis. The remaining articles were examined for three criteria: key words throughout the text such as message, audience, or vehicle; a 
clearly articulated strategic communication plan, goal, or a framework; and, whether examples of implementing a strategic communication plan were included (e.g., case studies). A separate, additional literature analysis examined specific journals such as Science Communication, the International Journal of Strategic Communication, and the Proceedings of the National Academy of Science for any missing sources or materials.

Additionally, we identified examples from U.S. federal agencies and environmental non-governmental organizations (ENGOs) in the grey literature on strategic communication efforts in the natural sciences. The Google search engine was used to identify relevant natural science federal agencies and ENGOs using the keywords "strategic communication plan," and websites for each relevant source were then searched using the same keywords. The natural sciences peer-reviewed publications and ENGO sources are cited in the Appendix, along with strategic communication elements identified for each source.

Common elements and important process steps in developing a strategic communication plan were identified through this literature review. As no generalizable framework for developing a strategic communication plan was identified from this literature review, we compiled elements of strategic communication and developed a strategic communication framework presented here (Fig. 1). While none of the individual framework elements are novel within the field of science communication, developing a generalizable overall framework tailored to the needs of scientists represents an important advancement in strategic communication for EBM practitioners, and the larger suite of natural sciences in general. In addition to outlining this framework, we present one approach for operationalizing strategic communication through development of a Strategic Communication Matrix.

\section{Generalized Framework Development for Strategic Communication in Ecosystem-Based Management and the Natural Sciences}

Three interlinked pillars of message, audience, and vehicle, built on clearly articulated goals, form the core of a generalizable framework (Fig. 1). The first step in the generalized framework is establishing project goals and objectives (Step 1). Once project goals are identified, communication goals (Step 2) can be derived and help drive the communication process and aid in accomplishing project goals and objectives. Many natural science papers identified establishing communication goals as one of the first steps in a strategic communication plan (Bronson 2004; Dayer and Meyers 2012; Timm et al. 2016). When identifying communications goals, decision makers and stakeholders must ask themselves what they are trying to achieve with their communication efforts. All too often, decision makers and stakeholders fall into the trap of communicating information for the sake of the information itself. In the framework presented here, when setting a communication goal, the question 


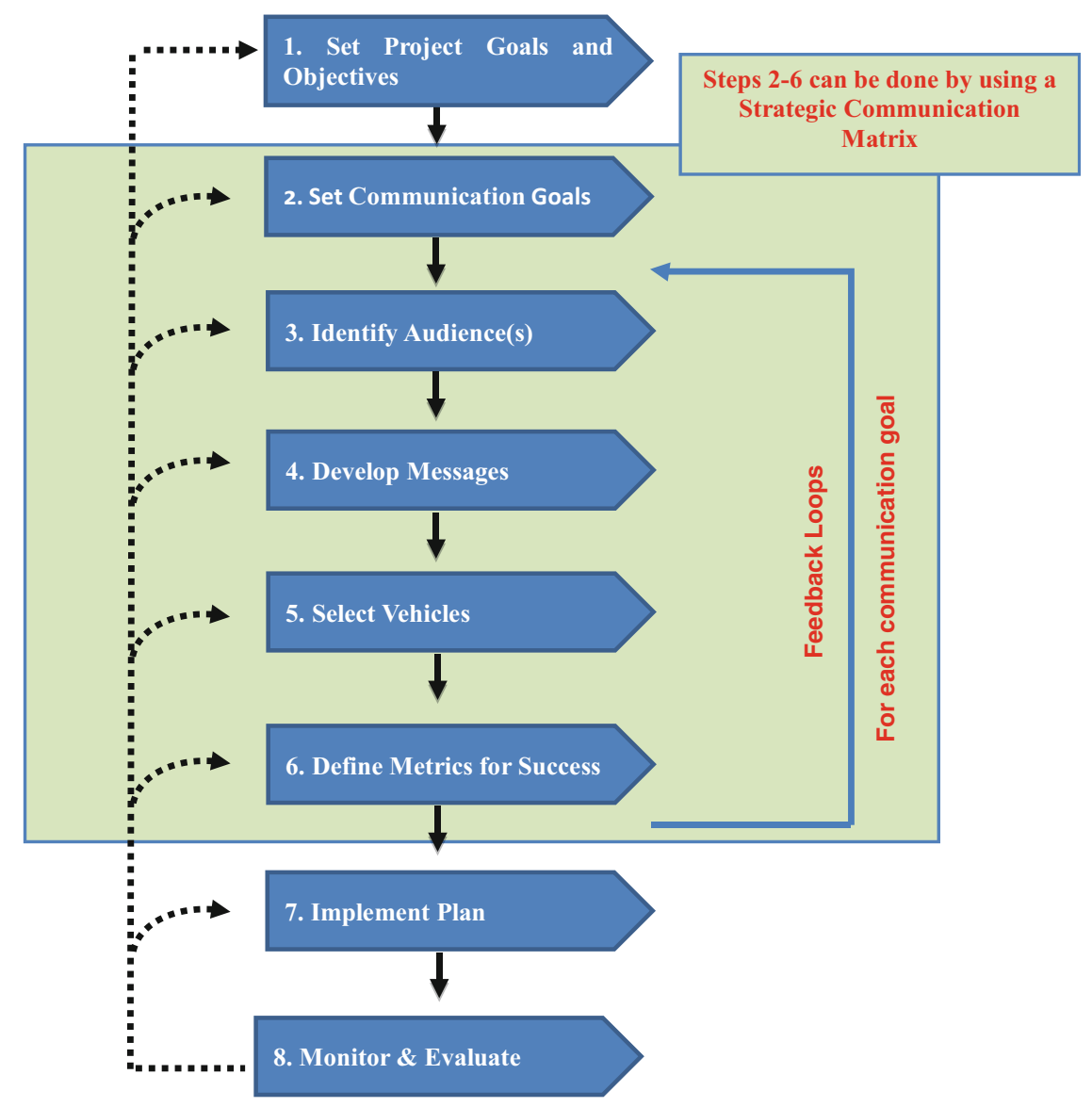

Fig. 1 Generalizable Strategic Communication Conceptual Framework using a Strategic Communication Matrix

decision makers and stakeholders must ask themselves is, "What are they trying to achieve?" The decision makers and stakeholders in this example may have several goals obscured under the more nebulous idea of "communicating the importance" of a science topic or decision. These goals could range from wanting to share their results or decisions with fellow stakeholders, to wanting to garner support for future work from stakeholders, to wanting to encourage external decision makers to incorporate scientific findings into their decision-making processes.

Using an example of ecosystems services to inform EBM, a more outcomefocused version of a communication goal could be "demonstrate how using the concept of ecosystem services could improve decisions related to human health and well-being." This type of goal could be identified as part of a larger effort to introduce the concepts of applying ecosystem services to inform decision making in general (e.g., DeWitt et al. 2020) as a way to present the desire to apply a similar 
approach in another decision context. In this text, examples include the use of ecosystem services assessment mapping for communicating future decision scenarios in Long Island (Myer and Johnston 2020), the articulation of ongoing ecosystem services consideration in EBM of the Vouga estuary (Lillebø et al. 2020), or the development of new applications of ecosystem services concepts, such as the ecosystem services gradient framework (Yee et al. 2020).

Identifying a project's communication audience (Step 3) includes identifying what the audience(s) already knows, what communicators would like them to know, how the audience gets information, and what the communicators would like those involved in the project to know (Groffman et al. 2010). As the communication plan is being developed and implemented, strategic communicators will gain more information about the knowledge base and values of different target audiences because a two-way communication approach, critical for effective EBM practices (Long et al. 2015), allows for feedback and evaluation. The selection of audiences, those groups who should be targeted to achieve those goals (USFWS 2016), organically follows identification of communication goals. Driscoll et al. (2012) examined a series of Long Term Ecological Reserve case studies that successfully built relationships between science and policy by focusing on engagement and distillation of results through media that met the needs of diverse audiences. Their case studies showcase programs that engage with decision makers on various issues through different communication approaches, which are determined by the audience of decision makers and the context and issues (i.e., messages) being addressed (Driscoll et al. 2012).

In an EBM context, the importance of two-way communication has been long established, including historical connections to the conservation literature, focusing on communication among relevant stakeholders as needing to be interactive and continuous. To learn more about the role of stakeholder engagement in socioecological decision-making contexts such as EBM, the reader is directed to examples such as Newton and Elliott (2016) and Lillebø et al. (2020). Recent advances in approaching prioritization of stakeholders in natural sciences are identified in Sharpe et al. (2020).

Developing appropriate messages for each goal and audience (Step 4) is more detailed and less organic than audience identification. Audiences approach a message with their own backgrounds, ideas, attitudes, and beliefs that must be acknowledged in developing successful messages (Barker 2006; Halpern et al. 2012). Developing clear messages for different stakeholders or audiences is important for promoting the responses intended by communicators and ensuring that identified goals and objectives are being met (USFWS 2016). Several natural science papers highlighted establishing effective, multi-party communication among decision makers, scientists, and community members, which led to more successful science and management (Leong et al. 2008; DeLauer et al. 2012). Message development must be done with the audiences' perspectives in mind. For example, if a communications program goal is to get recreational fishermen to comply with a licensing requirement, messaging that urges compliance should include language on how compliance helps achieve fishing community goals (e.g., licensing leads to more 
accurate estimates of fish populations which leads to more sustainable fishing, allowing fishing to be available to future generations).

Identifying specific communication vehicles (Step 5) will depend on what is known about the audience and is selected based on communication goals. The USFWS (2016) discusses selecting tactics, tools, and channels based upon the target audience, and Hobbs (2006) reminds the reader to "choose your medium carefully." The potential effectiveness of a communication vehicle can also be used to steer a science communication effort. Within the Tonle Sap Region of Cambodia, the Participatory Natural Resources Management Team recognized their target communication audiences were made up of different ethnic groups, languages, and religions, and they found meetings, workshops, posters, and environmental educators were the most effective communication vehicles for success of their communication goals (Thompson 2006). Additionally, Thompson (2006) recognized that vehicles which did not involve community members in development or interpretation process had very limited impact.

When outlining the messages/audiences/vehicles for each communication goal, metrics of success (Step 6) can be identified (e.g., NOAA 2009; Sea Grant 2003; NASEM 2006; USFWS 2014; NPS 2016) and used during implementation of a strategic communication plan and in efforts to monitor and evaluate the strategic communication plan. Metrics can focus on a specific aspect of communication (e.g., effectiveness of a given presentation to a particular audience), or a more comprehensive aspect (e.g., metrics that should be tracked to learn whether overall communication goals are met).

The approach for implementing a strategic communication plan should be tied back to overarching communication and project goals and may include establishing a shared understanding between science communicators and the audience. Operationally, the strategic communication plan is implemented with both content development and delivery in different forums (Step 7). Recognizing that what is persuasive for one audience may not be for another, a single project can have multiple messages, but targeted differently. Targeted messages could be as simple as having different sets of fact sheets for different regions, each highlighting regionally specific work. Additionally, different aspects of a larger project may have targeted messages for a particular audience. A Strategic Communication Matrix is one way to organize elements of a communication plan to help track and implement more sophisticated approaches to communications (e.g., more components or more complex sets of messages/audiences/vehicles) around a larger project. We present a hypothetical example in Table 1 demonstrating using a matrix to understand how different elements within the plan relate to, and rely upon, one another. More complex Strategic Communication Matrices can be operational in nature, including capturing additional metadata and tracking information.

Evaluations and feedback loops are critical to a strategic communication plan (Step 8). Interacting with intended audiences and/or stakeholders on a regular basis is important to ensure that messages are being received and having the intended impact. Further, it is important that communicators understand how audiences are responding to messages and whether adjustments are needed. These feedback loops 
Table 1 Example template of a Strategic Communication Matrix

\begin{tabular}{|c|c|c|c|c|}
\hline Project goal & \multicolumn{4}{|c|}{$\begin{array}{l}\text { Insert Project Goal } 1 \text { here. This template can be adjusted to fit your project } \\
\text { needs based on the identified project goal. }\end{array}$} \\
\hline $\begin{array}{l}\text { Project } \\
\text { sub-goals }\end{array}$ & \multicolumn{4}{|c|}{$\begin{array}{l}\text { Insert Project Sub-goal } 1 \text { here. This is the first sub-goal necessary in aiding } \\
\text { and accomplishing project goal } 1 .\end{array}$} \\
\hline $\begin{array}{l}\text { Communication } \\
\text { goals }\end{array}$ & \multicolumn{2}{|c|}{$\begin{array}{l}\text { Insert Communication Goal } 1 \text { here. } \\
\text { This is the first communication goal } \\
\text { necessary in aiding and accomplishing } \\
\text { Sub-Goal 1. Ask "What are you trying } \\
\text { to achieve?" }\end{array}$} & \multicolumn{2}{|c|}{$\begin{array}{l}\text { Insert Communication Goal } 2 \text { here. } \\
\text { This is the second communication } \\
\text { goal necessary in aiding and } \\
\text { accomplishing sub-goal 1. Ask } \\
\text { "What are you trying to achieve?" }\end{array}$} \\
\hline Audiences & $\begin{array}{l}\text { Insert Audience } 1 \\
\text { here. This is the } \\
\text { first group } \\
\text { targeted to } \\
\text { achieve Commu- } \\
\text { nication Goal } 1 .\end{array}$ & $\begin{array}{l}\text { Insert Audience } 2 \\
\text { here. This is the } \\
\text { second group } \\
\text { targeted to } \\
\text { achieve Commu- } \\
\text { nication Goal } 1 .\end{array}$ & $\begin{array}{l}\text { Insert Audience } \\
1 \text { here. This is } \\
\text { the first group } \\
\text { targeted to } \\
\text { achieve Com- } \\
\text { munication Goal } \\
2 .\end{array}$ & $\begin{array}{l}\text { Insert Audience } \\
2 \text { here. This is } \\
\text { the second } \\
\text { group targeted to } \\
\text { achieve Com- } \\
\text { munication Goal } \\
2 .\end{array}$ \\
\hline Messages & $\begin{array}{l}\text { Insert list of mes- } \\
\text { sages here. These } \\
\text { messages are } \\
\text { appropriate in } \\
\text { aiding and } \\
\text { accomplishing } \\
\text { Communication } \\
\text { Goal } 1 \text { and are } \\
\text { specific to the } \\
\text { targeted group } \\
\text { identified as } \\
\text { Audience } 1 .\end{array}$ & $\begin{array}{l}\text { Insert list of mes- } \\
\text { sages here. These } \\
\text { messages are } \\
\text { appropriate in } \\
\text { aiding and } \\
\text { accomplishing } \\
\text { Communication } \\
\text { Goal } 1 \text { and are } \\
\text { specific to the } \\
\text { targeted group } \\
\text { identified as } \\
\text { Audience } 2 .\end{array}$ & \multicolumn{2}{|c|}{$\begin{array}{l}\text { Insert list of messages here. These } \\
\text { messages are appropriate in aiding } \\
\text { and accomplishing Communication } \\
\text { Goal } 2 \text { for both Audience } 1 \text { and } \\
\text { Audience } 2 \text { and are specific to the } \\
\text { targeted groups identified as Audi- } \\
\text { ence } 1 \& 2 \text {. }\end{array}$} \\
\hline Vehicles & $\begin{array}{l}\text { Insert a list of } \\
\text { vehicles here that } \\
\text { is specific to } \\
\text { Audience } 1 \text { and } \\
\text { their messages. }\end{array}$ & $\begin{array}{l}\text { Insert a list of } \\
\text { vehicles here that } \\
\text { is specific to } \\
\text { Audience } 2 \text { and } \\
\text { their messages. }\end{array}$ & \multicolumn{2}{|c|}{$\begin{array}{l}\text { Insert a list of vehicles here that is } \\
\text { specific to Audience } 1 \& 2 \text { and their } \\
\text { messages. }\end{array}$} \\
\hline Metrics & $\begin{array}{l}\text { Insert a list of } \\
\text { metrics for suc- } \\
\text { cess. These met- } \\
\text { rics aid in } \\
\text { monitoring and } \\
\text { evaluating the } \\
\text { success of com- } \\
\text { municating Com- } \\
\text { munication Goal } \\
1 \text { with Audience } \\
1 .\end{array}$ & $\begin{array}{l}\text { Insert a list of } \\
\text { metrics for suc- } \\
\text { cess. These met- } \\
\text { rics aid in } \\
\text { monitoring and } \\
\text { evaluating the } \\
\text { success of com- } \\
\text { municating Com- } \\
\text { munication Goal } \\
1 \text { with Audience } \\
2 .\end{array}$ & \multicolumn{2}{|c|}{$\begin{array}{l}\text { Insert a list of metrics for success. } \\
\text { These metrics aid in monitoring and } \\
\text { evaluating the success of communi- } \\
\text { cating Communication Goal } 2 \text { with } \\
\text { Audience } 1 \& 2 \text {. }\end{array}$} \\
\hline
\end{tabular}

This matrix can be expanded or collapsed based on project needs to include as many communication goals, audiences, messages, vehicles, and metrics are necessary to aid in accomplishing a project goal 
are iterative in nature and ideally occurring throughout the project (e.g., getting feedback on each communication effort as it occurs). It is only by providing mechanisms to learn how a given audience responds that practitioners can refine and improve efforts (Hartman and Lenk 2001; LTER Network 2010; Okaka 2010; USFWS 2013; Ferguson 2015). The framework in Fig. 1 presents the need for both iterative development (e.g., NOAA 2016) and feedback loops throughout the strategic communication process (Table 1).

\section{Ecosystem Services in an Ecosystem-Based Management Case Study}

Ecosystem services, also referred to as the "benefits of nature," involve the identification and valuation of ecosystem attributes that benefit humans. Changes in final ecosystem goods and services (FEGS, or Final EGS), those services that directly benefit people (Landers and Nahlik 2013; DeWitt et al. 2020), can translate into changes in human health and well-being. An example Strategic Communication Matrix illustrates how to implement and track communication goals and messages (Tables 2 and 3) for an ecosystem services application in an EBM context.

In our example, the project goal is to examine and quantify how the supply and benefits of FEGS are delivered to different populations within a community as it relates to informing a specific EBM context (de Jesus Crespo and Fulford 2018). The studies within this goal involve identifying community-based preferences and values for natural resources, conducting quantitative modeling of FEGS and their benefits for human health, and exploring relationships between ecosystem services and human health, all in the context of the EBM decision at hand. This overarching project goal has multiple sub-goals, each having its own set of communication goals (Table 2). For example, the first project sub-goal focused on demonstrating the value of the concept of beneficiaries to stakeholders. To achieve this goal, several separate communications goals have been articulated, each aimed at achieving a different purpose with their respective target audiences (Table 2):

1. Clearly explain the concept of beneficiaries (those that receive the benefits provided by the ecosystem good or service) in EBM decision contexts. This goal is one of information transfer, in particular, supporting the establishment of a shared understanding of terminology.

2. Demonstrate how using the concept could influence existing EBM decisionmaking processes. This goal is aimed at building support for the work, getting buy-in among target audiences (in this case, the EBM stakeholders), and recognition of the coupled socio-ecological system (Long et al. 2015).

3. Understand what, if any, concepts are currently being used in place of the one proposed. This goal is aimed at expanding scientists' understanding of how their work is being received; the use of scientific knowledge in an integrated management context are both core EBM principles (Long et al. 2015). 


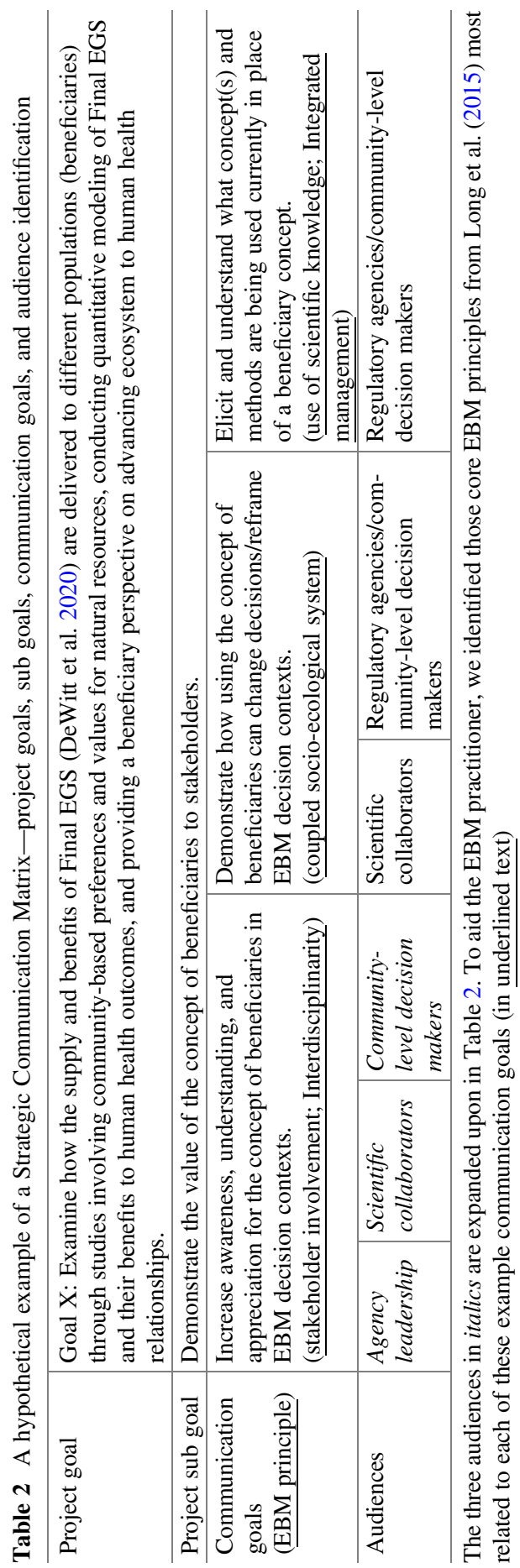


Table 3 A hypothetical example of a Strategic Communication Matrix-Audience identification, messages, vehicles, and metrics

\begin{tabular}{|c|c|c|c|}
\hline Audiences & Agency leadership & $\begin{array}{l}\text { Scientific } \\
\text { collaborators }\end{array}$ & Community-level decision makers \\
\hline Messages & \multicolumn{2}{|c|}{$\begin{array}{l}\text { • Beneficiaries are "the interests of an } \\
\text { individual (i.e., person, organization, } \\
\text { household, or firm) that drive active or pas- } \\
\text { sive consumption and/or appreciation of } \\
\text { ecosystem services resulting in an impact } \\
\text { (positive or negative) on their welfare." } \\
\text { • Identifying beneficiaries allows } \\
\text { researchers and decision makers to solicit } \\
\text { input from groups that may be affected by } \\
\text { changes in ecosystem goods and services, } \\
\text { and to target beneficiary groups of interest. } \\
\text { • Future work on beneficiaries will be } \\
\text { used to identify how the benefits of Final } \\
\text { EGS are delivered to different populations } \\
\text { through EBM-related studies involving } \\
\text { community-based preferences and modeling } \\
\text { of Final EGS and their benefits to human } \\
\text { health outcomes. }\end{array}$} & $\begin{array}{l}\text { - Beneficiaries are "the interests of } \\
\text { an individual (i.e., person, organiza- } \\
\text { tion, household, or firm) that drive } \\
\text { active or passive consumption and/or } \\
\text { appreciation of ecosystem services } \\
\text { resulting in an impact (positive or } \\
\text { negative) on their welfare." } \\
\text { - The concept of beneficiaries is } \\
\text { useful in EBM decision contexts } \\
\text { because it directly connects those } \\
\text { who benefit from the environment to } \\
\text { the ways in which they benefit }\end{array}$ \\
\hline Vehicles & $\begin{array}{l}\text { - Internal reports } \\
\text { - Newsletters } \\
\text { - Presentations } \\
\text { to leadership }\end{array}$ & $\begin{array}{l}\text { - Peer-reviewed } \\
\text { journal articles } \\
\text { - Conference } \\
\text { presentations }\end{array}$ & $\begin{array}{l}\text { - Presentations or webinars to } \\
\text { community planning groups } \\
\text { - Plain language web page }\end{array}$ \\
\hline Metrics & $\begin{array}{l}\text { - Sharing project } \\
\text { results up the chain } \\
\text { - Publicizing } \\
\text { project results } \\
\text { - Continued sup- } \\
\text { port for the } \\
\text { research to } \\
\text { continue }\end{array}$ & $\begin{array}{l}\text { - Citations of work } \\
\text { on beneficiaries } \\
\text { - Publications of } \\
\text { work using the bene- } \\
\text { ficiaries concept }\end{array}$ & $\begin{array}{l}\text { - Recognition and comprehension } \\
\text { of the concept of beneficiaries } \\
\text { - Agreement that the concept of } \\
\text { beneficiaries would be useful in } \\
\text { EBM-related decision making }\end{array}$ \\
\hline
\end{tabular}

This example is for the first communication goal identified in Table 2

In this example, the first goal focuses on providing foundational information. While the first goal does not directly focus on the science, communications may have to go beyond the bounds of the specific research in order to set the stage properly. The importance of setting the stage is underscored in the ecosystem services example, where the general public may not be aware - or supportive - of ecosystem services per se but does see the value in the concepts (and language) of the "benefits of nature" (Metz and Weigel 2013). The second goal focuses on messages specifically related to the science. The third goal gives an example of two-way communication that should be fostered in a strategic communication plan so that scientists are able to refine their scientific research and messaging to reflect the audience's needs and values. As these are done for a specific EBM context, communication goals may change as the EBM context changes. 
For the first of these communication goals, three specific audience types were identified-agency leadership, scientific collaborators, and community-level decision makers (Table 2). In developing the actual plan, these audiences may be broken down further for more specific identification and targeting of messages. In our example Strategic Communication Matrix, we built upon the first communication goal in Table 2 and different messages were identified for the various audiences (Table 3). In this example, for this communication goal, one set of messages was aimed at agency leadership and scientific collaborators, and another set aimed at community-level decision makers. Although there is overlap between the sets of messages, they are differentiated by what they are attempting to achieve. When focusing on agency leadership and scientific collaborators, project communicators hope to build an understanding of the concept of beneficiaries, so it is considered in future planning efforts. With community-level decision makers, the messaging is aimed at showing how the concept of beneficiaries would specifically be useful to them in their work.

All messages are aimed at clearly explaining the concept of beneficiaries, but they are crafted with targeted audiences in mind. In this scenario, incorporating ecosystem services into EBM decision processes is done through the use of a "FEGS approach"- one that focuses on beneficiaries and their role in defining and articulating relevant ecosystem services for a given decision context (DeWitt et al. 2020). This represents only one of several ways to present ecosystem services information into the decision process. Other approaches, such as those focused on capturing the supply of ecosystem services (e.g., Lillebø et al. 2020; Myer and Johnston 2020) might have different communication goals related to identifying stakeholders or recipients of nature's benefits. A strategic communication approach can be useful for capturing information about those different approaches, focused on different target audiences, allowing for different target audiences to learn more to answer their different questions. For a discussion on the overall FEGS approach, the reader is directed to DeWitt et al. (2020); for more discussion on the value and approach of engaging with beneficiaries with this approach, the reader is directed to Sharpe et al. (2020).

Different sets of vehicles and metrics are identified for each targeted audience (Table 3). Even though the same set of messages is being targeted at agency leadership and scientific collaborators, the strategic communication plan recognizes that peer-reviewed journal articles and conference presentations that are successful at spreading their message to scientific collaborators would be far less effective in communicating to agency leadership. Similarly, success in communicating the concept of beneficiaries for consideration in future work looks very different to these two audiences. For agency leadership, successful communication is measured, in part, by continued support for the science, whereas successful communication with scientific collaborators is measured by seeing them use the beneficiaries concept in their own work on EBM decisions. When designing metrics for specific communication goals, the strategic communication plan approach asks the planner to consider what outcomes they are hoping to see overall and with each targeted audience. 
It is easy to see how the complexity of strategic communication planning can increase exponentially when considering a large project in its entirety, underscoring the importance of a strategic communication plan and the value of a well-designed Strategic Communication Matrix. In our example, communicating the science on ecosystem services and its role with targeted beneficiaries within a larger EBM decision context through the use of a Strategic Communication Matrix allows advances in strategic communications for: (1) considering the full set of communication goals in a coordinated fashion; (2) finding opportunities for coordination across project goals; (3) finding ways to combine messaging associated with separate communication goals aimed at the same audience; and (4) leveraging limited resources into a more focused and outcome-driven communication effort.

\section{Conclusion}

Traditionally, the work of strategic communications has been done by individuals and organizations other than those conducting the research and making the decisions. We suggest that research projects and management plans benefit when scientists and decision makers proactively engage in the communication process from the beginning. This engagement allows them to focus the science and decisions in ways that resonate with targeted audiences and to share the work in ways more likely to have an impact; this aligns strongly with the core EMB principle of recognizing the coupled socio-ecological nature of the system. Although scientists and managers may have not traditionally been expected or trained to participate in communication work, the strategic communication framework laid out here (the three interlinked pillars of message, audience, and vehicle, resting on a common foundation of communication goals) can be used as a template. To be most effective, there needs to be buy-in, from an organizational perspective, on the effort required to build and implement a plan. The core EBM principle of stakeholder involvement calls for development of a strategic communication element in an EBM program.

An example in the interdisciplinary field of ecosystem services science was presented to demonstrate how to develop a clear and simple matrix to provide a visual roadmap for communication and to help coordinate efforts across a project. The use of a generalizable framework and a strategic communication matrix allows science and decision communications to be pursued using a systems-thinking approach. The EBM core principle of the use of scientific knowledge calls for practitioners to share their results or decisions with fellow scientists and stakeholders, garner support for future work from funding institutions, or encourage external decision makers to incorporate findings into decision-making processes. All scientists, decision makers, and stakeholders have project goals related to multiple audiences. The framework and matrix laid out here provide a pathway to help those scientists, decision makers, and stakeholders take a strategic approach in using communication efforts to help achieve their communication goals for their audiences. This approach expands scientific communication from the old deficit 
model, in which the primary goal was to make information available, towards a model that recognizes communication can be an invaluable tool in achieving science and management goals.

While the idea of strategic communication exists in the literature, the practice seems to be underutilized by scientists, decision makers, and stakeholders in general, including EBM practitioners. Those scientists, decision makers, and stakeholders who might be using the concept of strategic communication are not discussing their efforts in the peer-reviewed literature. Those that are publishing it in the literature are typically proposing strategic communication plans for future projects, rather than following up with the results of implementation and analysing whether or not communication improved. Therefore, our assumption of a lack of strategic communication plans/frameworks used among scientists, decision makers, and stakeholders may be overly simplistic. We hope that this chapter can encourage EBM practitioners to be more open/transparent about their science, decision making, management, and communication efforts in order to help the scientific community better communicate results. For strategic communication efforts that may have already taken place, but are unacknowledged in the peer-reviewed literature, a useful next step could be an effort to survey scientists, decision makers, and stakeholders to examine the question of their communication practices. This approach could give a more accurate picture of the state of strategic communication work being done by EBM practitioners.

Disclaimer This chapter has been subjected to Agency review and has been approved for publication. The views expressed in this paper are those of the author(s) and do not necessarily reflect the views or policies of the U.S. Environmental Protection Agency.

\section{Appendix}

Search results from both the literature (top table) and government and ENGO reports (bottom table)

\begin{tabular}{|c|c|}
\hline Citation & $\begin{array}{l}\text { Elements }(\mathrm{G}=\text { Goals; } \mathrm{M}=\text { Message; } \\
\mathrm{A}=\text { Audience; } \mathrm{V}=\mathrm{Vehicle} \text {; } \mathrm{T}=\text { Two- } \\
\text { way Communication; } \mathrm{S}=\text { Metrics for } \\
\text { Success })\end{array}$ \\
\hline $\begin{array}{l}\text { Bronson, D. (2004). Engaging Canadians: Build- } \\
\text { ing Professional Communications in Parks } \\
\text { Canada. Communicating Protected Areas } \\
\text { pp. } 61-68 .\end{array}$ & $\mathrm{G}, \mathrm{M}, \mathrm{A}, \mathrm{V}$ \\
\hline $\begin{array}{l}\text { Day, B.A. and M.C. Monroe. (2000). Environ- } \\
\text { mental Education and Communication for a Sus- } \\
\text { tainable World: Handbook for International }\end{array}$ & $\mathrm{G}, \mathrm{M}, \mathrm{A}, \mathrm{V}$ \\
\hline
\end{tabular}




\begin{tabular}{|c|c|}
\hline Citation & $\begin{array}{l}\text { Elements }(\mathrm{G}=\text { Goals; } \mathrm{M}=\text { Message; } \\
\mathrm{A}=\text { Audience; } \mathrm{V}=\mathrm{Vehicle} ; \mathrm{T}=\text { Two- } \\
\text { way Communication; } \mathrm{S}=\text { Metrics for } \\
\text { Success })\end{array}$ \\
\hline \multicolumn{2}{|l|}{$\begin{array}{l}\text { Practitioners. Academy for Educational Develop- } \\
\text { ment, Washington, DC. } 141 \mathrm{pp} \text {. }\end{array}$} \\
\hline $\begin{array}{l}\text { Dayer, A. and R.M. Meyers. (2012). Appalachian } \\
\text { Mountains Joint Venture Strategic Communica- } \\
\text { tions Plan 2013-2017. Communications Report } \\
\text { 2012-01, Skaneateles, NY. } 62 \text { pp. } \\
\end{array}$ & $\mathrm{G}, \mathrm{M}, \mathrm{A}, \mathrm{V}, \mathrm{T}$ \\
\hline $\begin{array}{l}\text { DeLauer, V., S. Ryan, I. Babb, P. Taylor, and } \\
\text { P. Di-Bona. (2012). Linking Science to Manage- } \\
\text { ment and Policy through Strategic Communica- } \\
\text { tion. Advancing an Ecosystem Approach in the } \\
\text { Gulf of Maine. Stephenson, R.L., J.H. Annala, } \\
\text { J.A. Runge and M. Hall-Arber (eds.). American } \\
\text { Fisheries Society, Symposium 79:89-101. }\end{array}$ & $\mathrm{M}, \mathrm{A}, \mathrm{V}, \mathrm{T}$ \\
\hline $\begin{array}{l}\text { Driscoll, C.T., K.F. Lambert, F.S. Chap-in III, } \\
\text { D.J. Nowak, T.A. Spies, F.J. Swanson, } \\
\text { D.B. Kittredge, and C.M. Hart. (2012). Science and } \\
\text { society: The role of long-term studies in environ- } \\
\text { mental stewardship. BioScience, 62(4):354-366. }\end{array}$ & $\mathrm{G}, \mathrm{M}, \mathrm{A}, \mathrm{V}, \mathrm{T}, \mathrm{S}$ \\
\hline $\begin{array}{l}\text { Ekebom, J., J. Jäänheimo, J. Reker, M. Kindström, } \\
\text { C. Lindblad, A. Mattisson, A. Sandstrom, and } \\
\text { V. Jermakovs. (2008). Towards Marine Spatial } \\
\text { Planning in the Baltic Sea. BALANCE Technical } \\
\text { Summary Report 4(4). }\end{array}$ & $\mathrm{G}, \mathrm{M}, \mathrm{A}, \mathrm{V}, \mathrm{S}$ \\
\hline $\begin{array}{l}\text { Ferguson, D.B. (2015). Linking Environmental } \\
\text { Research and Practice: Lessons from the Integra- } \\
\text { tion of Climate Science and Water Management in } \\
\text { the Western United States. } 2015 \text { AGU Fall } \\
\text { Meeting. }\end{array}$ & $\mathrm{M}, \mathrm{T}$ \\
\hline $\begin{array}{l}\text { Goldberg, J., N. Marshall, A. Birtles, P. Case, } \\
\text { E. Bohensky, M. Curnock, M. Gooch, H. Parry- } \\
\text { Husbands, P. Pert, R. Tobin, C. Villani, and } \\
\text { B. Visperas. (2016). Climate change, the Great } \\
\text { Barrier Reef and the response of Australians. Pal- } \\
\text { grave Communications, 2:15046. }\end{array}$ & $\mathrm{M}, \mathrm{A}, \mathrm{V}, \mathrm{T}$ \\
\hline $\begin{array}{l}\text { Groffman, P.M., C. Stylinski, M.C. Nisbet, } \\
\text { C.M. Duarte, R. Jordan, A. Burgin, M.A. Previtali, } \\
\text { and J. Coloso. (2010). Restarting the conversation: } \\
\text { Challenges at the interface between ecology and } \\
\text { society. Frontiers in Ecology and the Environment, } \\
\text { 8(6):284-291. }\end{array}$ & $\mathrm{A}, \mathrm{V}, \mathrm{T}$ \\
\hline $\begin{array}{l}\text { Halpern, B.S., J. Diamond, S. Gaines, S. Gelcich, } \\
\text { M. Gleason, S. Jennings, S. Lester, A. Mace, } \\
\text { L. McCook, K. McLeod, N. Napoli, K. Rawson, } \\
\text { J. Rice, A. Rosenberg, M. Ruckelshaus, B. Saier, } \\
\text { P. Sandifer, A. Sholtz, and A Zivian. (2012). Near- } \\
\text { term priorities for the science, policy and practice } \\
\text { of Coastal and Marine Spatial Planning (CMSP). } \\
\text { Marine Policy, 36(1):198-205. }\end{array}$ & $\mathrm{M}, \mathrm{A}, \mathrm{V}, \mathrm{T}$ \\
\hline
\end{tabular}




\begin{tabular}{|c|c|}
\hline Citation & $\begin{array}{l}\text { Elements }(\mathrm{G}=\text { Goals; } \mathrm{M}=\text { Message; } \\
\mathrm{A}=\text { Audience; } \mathrm{V}=\mathrm{Vehicle} ; \mathrm{T}=\text { Two- } \\
\text { way Communication; } \mathrm{S}=\text { Metrics for } \\
\text { Success })\end{array}$ \\
\hline $\begin{array}{l}\text { Hesselink, F., W. Goldstein, P.P. van Kempen, } \\
\text { T. Garnett, and J. Dela. (2007). Communication, } \\
\text { Education, and Public Awareness (CEPA): A toolkit } \\
\text { for National Focal Points and NBSAP Coordina- } \\
\text { tors. Secretariat of the Convention on Biological } \\
\text { Diversity and IUCN, Montreal, Canada. } 310 \text { pp. }\end{array}$ & $\mathrm{M}, \mathrm{A}, \mathrm{V}, \mathrm{T}$ \\
\hline $\begin{array}{l}\text { Kellam, D. (2004). New Hampshire Estuaries } \\
\text { Project: Strategic Communication Plan. PREP } \\
\text { publications. } 17 \text { pp. }\end{array}$ & G, M, A \\
\hline $\begin{array}{l}\text { Lawas, T.P., M.S.C. Tirol, V.R. Cardenas, and } \\
\text { S.B. Jamias. (2010). Communication resource } \\
\text { mapping for coastal resources management of } \\
\text { Barangay Malabrigo, Lobo, Batangas, Philippines. } \\
\text { Journal of Environmental Science and Manage- } \\
\text { ment, 12(2):38-56. }\end{array}$ & $\mathrm{G}, \mathrm{M}, \mathrm{A}, \mathrm{V}$ \\
\hline $\begin{array}{l}\text { Leong, K.M., K.A. McComas, and D.J. Decker } \\
(2008) \text {. Formative coorientation research: A tool to } \\
\text { assist with environmental decision making. Envi- } \\
\text { ronmental Communication, 2(3):257-273. }\end{array}$ & A, S \\
\hline $\begin{array}{l}\text { Long-Term Ecological Research (LTER) Network. } \\
\text { (2010). LTER Strategic Communication Plan: } \\
\text { Bridging to Broader Audiences. } 55 \text { pp. }\end{array}$ & $\mathrm{G}, \mathrm{M}, \mathrm{A}, \mathrm{V}, \mathrm{S}$ \\
\hline $\begin{array}{l}\text { Okaka, W. (2010). Developing regional communi- } \\
\text { cations campaigns strategy for environment and } \\
\text { natural resources management policy awareness for } \\
\text { the East African community. Research Journal of } \\
\text { Environmental and Earth Sciences 2(2):106-111. }\end{array}$ & $\mathrm{G}, \mathrm{M}, \mathrm{A}, \mathrm{V}, \mathrm{T}$ \\
\hline $\begin{array}{l}\text { Smith, D. C., Smith, A. D. M., Dichmont, C., Steele, } \\
\text { W., \& Webb, H. (2014). Towards a strategic rela- } \\
\text { tionship between CSIRO and FRDC. Fisheries } \\
\text { Research and Development Corporation. } 36 \text { pp. }\end{array}$ & A, V, S \\
\hline $\begin{array}{l}\text { Thompson, J.S. (2006). Strategic Communication } \\
\text { in Community-Based Fisheries and Forestry: A } \\
\text { Case from Cambodia. In G. Bessette (Ed.), People, } \\
\text { Land, and Water: Participatory Development } \\
\text { Communication for Natural Resource Manage- } \\
\text { ment. International Development Research Centre } \\
\text { (IDRC), Ottawa, Canada. }\end{array}$ & $\mathrm{G}, \mathrm{M}, \mathrm{A}, \mathrm{V}, \mathrm{T}, \mathrm{S}$ \\
\hline $\begin{array}{l}\text { Timm, K., R. Hum, and M. Duckenmiller. (2016). } \\
\text { Using Communication Theory and Strategy to } \\
\text { Communicate Science and Build Stakeholder } \\
\text { Relationships in the Arctic. } 10 \mathrm{pp} .\end{array}$ & $\mathrm{G}, \mathrm{M}, \mathrm{A}, \mathrm{V}, \mathrm{T}$ \\
\hline $\begin{array}{l}\text { Velasco, M.T.H. (2006). Management and Imple- } \\
\text { mentation of Communication Programs for Natural } \\
\text { Resources Management in Agriculture. In: Informa- } \\
\text { tion and Communication for Natural Resource } \\
\text { Management in Agriculture: A Training Source- } \\
\text { book. College of Development Communication, } \\
\text { University of the Philippines Los Banos pp. 85-96. }\end{array}$ & G \\
\hline
\end{tabular}




\begin{tabular}{|c|c|}
\hline Citation & $\begin{array}{l}\text { Elements }(\mathrm{G}=\text { Goals; } \mathrm{M}=\text { Message; } \\
\mathrm{A}=\text { Audience; } \mathrm{V}=\mathrm{Vehicle} \mathrm{T}=\mathrm{Two}- \\
\text { way Communication; } \mathrm{S}=\text { Metrics for } \\
\text { Success })\end{array}$ \\
\hline $\begin{array}{l}\text { Vidal, R.M. and G. Lucia (2004). Strategic Com- } \\
\text { munication Planning for a National System of } \\
\text { Protected Areas, Mexico. Communicating } \\
\text { Protected Areas. Commission on Education and } \\
\text { Communication, Switzerland and Cambridge, UK, } \\
\text { pp. } 69-86 .\end{array}$ & $\mathrm{A}, \mathrm{V}, \mathrm{T}$ \\
\hline $\begin{array}{l}\text { Wiggill, M.N. (2014). Communicating for organi- } \\
\text { zational legitimacy: The case of the Potchefstroom } \\
\text { Fire Protection Association. Public Relations } \\
\text { Review 40(2):315-327. }\end{array}$ & $\mathrm{G}, \mathrm{A}$ \\
\hline $\begin{array}{l}\text { Winterfeldt, D.V. (2012). Bridging the gap } \\
\text { between science and decision making. Proceedings } \\
\text { of the National Academy of Sciences } \\
110(3): 14055-14061 .\end{array}$ & $\mathrm{M}, \mathrm{A}, \mathrm{T}$ \\
\hline
\end{tabular}

Citations are included and strategic communication elements are identified for each of the citations. This literature review identified the extent to which strategic communication is studied and incorporated into projects within the field of natural sciences, and allowed published efforts to organize, develop, and utilize a strategic communication plan in ecosystem-based management to be characterized

\begin{tabular}{|c|c|}
\hline Citation & $\begin{array}{l}\text { Elements }(\mathrm{G}=\text { Goals; } \mathrm{M}=\text { Message; } \\
\mathrm{A}=\text { Audience; } \mathrm{V}=\mathrm{Vehicle} \text {; } \mathrm{T}=\text { Two- } \\
\text { way communication; } \mathrm{S}=\text { Metrics for } \\
\text { Success })\end{array}$ \\
\hline $\begin{array}{l}\text { Africa Biodiversity Collaborative Group (ABCG), } \\
\text { (2004). Working together to help conserve Africa's } \\
\text { biodiversity—revised communications strategy. } \\
13 \text { pp. }\end{array}$ & $\mathrm{G}, \mathrm{M}, \mathrm{A}, \mathrm{V}$ \\
\hline $\begin{array}{l}\text { International Union for Conservation of Nature. } \\
\text { (2016). Communications strategy Sri Lanka- } \\
\text { global forest governance project: Strengthening } \\
\text { voices for better choices. } 38 \mathrm{pp} \text {. }\end{array}$ & $\mathrm{G}, \mathrm{M}, \mathrm{A}, \mathrm{V}, \mathrm{T}$ \\
\hline $\begin{array}{l}\text { National Academies of Sciences, Engineering, and } \\
\text { Medicine. (2006). Review of the Marine Recrea- } \\
\text { tional Information Program (MRIP). The National } \\
\text { Academies Press, Washington, DC. https://doi.org/ } \\
10.17226 / 24640 \text {. }\end{array}$ & $\mathrm{M}, \mathrm{A}, \mathrm{V}, \mathrm{T}, \mathrm{S}$ \\
\hline $\begin{array}{l}\text { National Marine Sanctuaries. (2003). Cordell } \\
\text { Bank, Gulf of the Farralones and Monterey Bay } \\
\text { National Marine Sanctuaries-strategic communi- } \\
\text { cation plan. } 10 \text { pp. }\end{array}$ & $\mathrm{G}, \mathrm{M}, \mathrm{A}, \mathrm{V}$ \\
\hline $\begin{array}{l}\text { National Oceanic and Atmospheric Administration } \\
\text { (NOAA) Office of Chief Information Officer. } \\
\text { (2009) Communications plan: Reliable and con- } \\
\text { sistent information exchange across NOAA's } \\
\text { information technology community. } 21 \mathrm{pp} .\end{array}$ & $\mathrm{G}, \mathrm{M}, \mathrm{A}, \mathrm{V}, \mathrm{S}$ \\
\hline
\end{tabular}




\begin{tabular}{|c|c|}
\hline Citation & $\begin{array}{l}\text { Elements }(\mathrm{G}=\text { Goals; } \mathrm{M}=\text { Message; } \\
\mathrm{A}=\text { Audience; } \mathrm{V}=\mathrm{Vehicle} \text {; } \mathrm{T}=\text { Two- } \\
\text { way communication; } \mathrm{S}=\text { Metrics for } \\
\text { Success })\end{array}$ \\
\hline $\begin{array}{l}\text { National Oceanic and Atmospheric Administration } \\
\text { (NOAA) Fisheries. (2016) NOAA Fisheries com- } \\
\text { munications implementation plan for the Pacific } \\
\text { Islands. U.S. Department of Commerce, National } \\
\text { Oceanic and Atmospheric Administration, National } \\
\text { Marine Fisheries Services. } 8 \text { pp. }\end{array}$ & $\mathrm{G}, \mathrm{M}, \mathrm{A}, \mathrm{V}, \mathrm{T}$ \\
\hline $\begin{array}{l}\text { National Park Service (NPS). (2016). Wildland fire } \\
\text { communication plan centennial edition: } \\
\text { 2016-2020. } 18 \text { pp. }\end{array}$ & $\mathrm{G}, \mathrm{M}, \mathrm{A}, \mathrm{T}, \mathrm{S}$ \\
\hline $\begin{array}{l}\text { Sea Grant (2003) Positioning Sea Grant-An Inte- } \\
\text { grated National Communications Plan. } \\
\text { 2003-2006. } 24 \text { pp. }\end{array}$ & $\mathrm{G}, \mathrm{M}, \mathrm{A}, \mathrm{V}, \mathrm{S}$ \\
\hline $\begin{array}{l}\text { US Fish and Wildlife Service. (2011). North } \\
\text { Atlantic LCC DRAFT communications strategy. } \\
14 \text { pp. }\end{array}$ & $\mathrm{G}, \mathrm{M}, \mathrm{A}, \mathrm{V}, \mathrm{T}$ \\
\hline $\begin{array}{l}\text { US Fish and Wildlife Service. (2013). Desert } \\
\text { Landscape Conservation Cooperative communi- } \\
\text { cations plan. } 13 \mathrm{pp} .\end{array}$ & $\mathrm{G}, \mathrm{M}, \mathrm{A}, \mathrm{V}$ \\
\hline $\begin{array}{l}\text { US Fish and Wildlife Service. (2014). Climate } \\
\text { change communications and engagement strategy } \\
\text { for the National Wildlife Refuge System. } 20 \text { pp. }\end{array}$ & $\mathrm{G}, \mathrm{M}, \mathrm{A}, \mathrm{V}, \mathrm{S}$ \\
\hline $\begin{array}{l}\text { US Fish and Wildlife Service. (2016). National } \\
\text { Wildlife Refuge System Communications Strat- } \\
\text { egy_final, February 1, 2016. } 25 \text { pp. }\end{array}$ & $\mathrm{G}, \mathrm{M}, \mathrm{A}, \mathrm{V}, \mathrm{T}$ \\
\hline
\end{tabular}

\section{References}

Africa Biodiversity Collaborative Group (ABCG). (2004). Working together to help conserve Africa's biodiversity-Revised communications strategy. In Department of Environmental Affairs, South Africa's National Biodiversity Strategy and Action Plan-2015-2025. Retrieved October 21, 2019, from https://www.environment.gov.za/sites/default/files/docs/publications/ SAsnationalbiodiversity_strategyandactionplan2015_2025.pdf.

Barker, S. (2006). Environmental communication in context. Frontiers in Ecology and the Environment, 4(6), 328-329.

Braus, J. (2009). Tools of engagement: How education and other social strategies can engage people in conservation action. Free Choice Learning and the Environment. Lanham, MD: AltaMira Press, pp. 87-104.

Bronson, D. (2004). Engaging Canadians: Building professional communications in parks Canada (pp. 61-68). Gland, Switzerland and Cambridge UK: IUCN Commission on Education and Communication.

Bubela, T., Nisbet, M. C., Borchelt, R., Brunger, F., Critchley, C., Einsiedel, E., \& Jandciu, E. W. (2009). Science communication reconsidered. Nature Biotechnology, 27(6), 514-518. 
Cabanero-Verzosa, C., \& Elaheebocus, N. (2008). Strategic communication in early childhood development programs: The case of Uganda (pp. 331-351). Washington, DC: The International Bank for Reconstruction and Development/The World Bank.

Day, B. A., \& Monroe, M. C. (2000). Environmental education and communication for a sustainable world: Handbook for international practitioners. Washington, DC: Academy for Educational Development.

Dayer, A., \& Meyers, R. M. (2012). Appalachian Mountains joint venture strategic communications plan 2013-2017. Communications Report 2012-01, Skaneateles, NY.

de Bruin, W. B., \& Bostrom, A. (2012). Assessing what to address in science communication. Proceedings of the National Academy of Sciences, 110(3), 14062-14068.

de Jesus Crespo, R., \& Fulford, R. (2018). Eco-health linkages: Assessing the role of ecosystem goods and services on human health using causal-criteria analysis. International Journal of Public Health, 63(1), 1-12.

DeLauer, V., Ryan, S., Babb, I., Taylor, P., \& Di-Bona, P. (2012). Linking science to management and policy through strategic communication. In R. L. Stephenson, J. H. Annala, J. A. Runge, \& M. Hall-Arber (Eds.), Advancing an ecosystem approach in the Gulf of Maine (Symposium), 79:89-101. Bethesda, MD: American Fisheries Society.

DeWitt, T. H., Berry, W. J., Canfield, T. J., Fulford, R. S., Harwell, M. C., Hoffman, J. C., Johnston, J. M., Newcomer-Johnson, T. A., Ringold, P. L., Russel, M. J., Sharpe, L. A., \& Yee, S. J. H. (2020). The final ecosystem goods and services (FEGS) approach: A beneficiarycentric method to support ecosystem-based management. In T. O’Higgins, M. Lago, \& T. H. DeWitt (Eds.), Ecosystem-based management, ecosystem services and aquatic biodiversity: Theory, tools and applications (pp. 127-148). Amsterdam: Springer.

Driscoll, C. T., Lambert, K. F., Chapin, F. S., III, Nowak, D. J., Spies, T. A., Swanson, F. J., et al. (2012). Science and society: The role of long-term studies in environmental stewardship. Bioscience, 62(4), 354-366.

Ekebom, J., Jäänheimo, J., Reker, J., Kindström, M., Lindblad, C., Mattisson, A., et al. (2008). Towards marine spatial planning in the Baltic Sea. Balance Technical Summary Report, 4(4). Retrieved October 21, 2019, from http://balance-eu.org/.

Ferguson, D. B. (2015). Linking environmental research and practice: Lessons from the integration of climate science and water management in the western United States. 2015 AGU Fall Meeting, San Francisco.

Goldberg, J., Marshall, N., Birtles, A., Case, P., Bohensky, E., Curnock, M., et al. (2016). Climate change, the great barrier reef and the response of Australians. Palgrave Communications, 2, 15046.

Groffman, P. M., Stylinski, C., Nisbet, M. C., Duarte, C. M., Jordan, R., Burgin, A., et al. (2010). Restarting the conversation: Challenges at the interface between ecology and society. Frontiers in Ecology and the Environment, 8(6), 284-291.

Hallahan, K., Holtzhausen, D., van Ruler, B., Vercic, D., \& Sriramesh, K. (2007). Defining strategic communication. International Journal of Strategic Communication, 1, 3-35.

Halloran, R. (2007). Strategic communication. Parameters, 37(3), 4.

Halpern, B. S., Diamond, J., Gaines, S., Gelcich, S., Gleason, M., Jennings, S., et al. (2012). Nearterm priorities for the science, policy and practice of coastal and marine spatial planning (CMSP). Marine Policy, 36(1), 198-205.

Hansen, J., Holm, L., Frewer, L., Robinson, P., \& Sandøe, P. (2003). Beyond the knowledge deficit: Recent research into lay and expert attitudes to food risks. Appetite, 41(2), 111-121.

Hartman, J., \& Lenk, M. M. (2001). Strategic communication capital as an intangible asset. International Journal on Media Management, 3(3), 147-153.

Hesselink, F., Goldstein, W., van Kempen, P. P., Garnett, T., \& Dela, J. (2007). Communication, education, and public awareness (CEPA): A toolkit for national focal points and NBSAP coordinators. Montreal: Secretariat of the Convention on Biological Diversity and IUCN.

Hobbs, R. (2006). Overcoming barriers to effective public communication of ecology. Frontiers in Ecology and the Environment, 4(9), 496-497. 
International Union for Conservation of Nature (IUCN). (2016). Communications strategy Sri Lanka-Global forest governance project: Strengthening voices for better choices. Forest Conservation Programme, Columbo, pp 38.

Jones, K., Baker, P., Doyle, J., Armstrong, R., Pettman, T., \& Waters, E. (2013). Increasing the utility of systematic reviews findings through strategic communication. Journal of Public Health, 35(2), 345-349.

Kellam, D. (2004). New Hampshire estuaries project: Strategic communication plan (227p.). Durham, New Hampshire: University of New Hampshire, PREP Publications.

Kellstedt, P. M., Zahran, S., \& Vedlitz, A. (2008). Personal efficacy, the information environment, and attitudes toward global warming and climate change in the United States. Risk Analysis, 28, $113-126$.

Landers, D. H., \& Nahlik, A. M. (2013). Final ecosystem goods and services classification system (FEGS-CS). EPA/600/R-13/ORD-004914. Washington, DC: U.S. Environmental Protection Agency, Office of Research and Development.

Lawas, T. P., Tirol, M. S. C., Cardenas, V. R., \& Jamias, S. B. (2010). Communication resource mapping for coastal resources management of Barangay Malabrigo, Lobo, Batangas, Philippines. Journal of Environmental Science and Management, 12(2), 38-56.

Leong, K. M., McComas, K. A., \& Decker, D. J. (2008). Formative coorientation research: A tool to assist with environmental decision-making. Environmental Communication, 2(3), 257-273.

Liang, Y., Kee, K. F., \& Henderson, L. K. (2018). Toward an integrated model of strategic environmental communication: Advancing theories of reactance and planned behavior in a water conservation text. Journal of Applied Communication Research, 46(2), 135-154.

Lilleb $\varnothing$, A. I., Teixeira, H., Martínez-López, J., Genua-Olmedo, A., Marhubi, A., Delacámara, G., Mattheiß, V., Strosser, P., O’Higgins, T., \& Nogueira, A. A. J. (2020). Mitigating negative unintended impacts on biodiversity in the Natura 2000 Vouga estuary (Ria de Aveiro, Portugal). In T. O’Higgins, M. Lago, \& T. H. DeWitt (Eds.), Ecosystem-based management, ecosystem services and aquatic biodiversity: Theory, tools and applications (pp. 461-498). Amsterdam: Springer.

Long, R. D., Charles, A., \& Stephenson, R. L. (2015). Key principles of marine ecosystem-based management. Marine Policy, 57, 53-60.

Long-Term Ecological Research (LTER) Network. (2010). LTER strategic communication plan: Bridging to broader audiences. Albuquerque, New Mexico.

Mattheiß V, Strosser P, Krautkraemer A, Charbonnier C, McDonald H, Röschel L, et al. (2018). Evaluation of ecosystem-based management responses in case studies: AQUACROSS Deliverable 8.2. European Union's Horizon 2020 Framework Programme for Research and Innovation Grant Agreement No. 642317. Retrieved October 20, 2019, from www.aquacross.eu.

Metz, D., \& Weigel, L. (2013). Language of conservation 2013: Updated recommendations on how to communicate effectively to build support for conservation. The Nature Conservancy. Retrieved October 20, 2019, from https://www.conservationgateway.org/Files/Pages/lan guage-conservation-mem.aspx.

Mortenius, H. (2014). Creating an interest in research and development as a means of reducing the gap between theory and practice in primary care: An interventional study based on strategic communication. International Journal of Environmental Research and Public Health, 11(9), 8689-8708.

Murphy, D. M. (2008). The trouble with strategic communication(s). Army War College, Center for Strategic Leadership, Carlisle Barracks, Pennsylvania.

Myer, M., \& Johnston, J. M. (2020). Models and mapping tools to inform resilience planning after disasters: A case study of hurricane Sandy and Long Island ecosystem services. In T. O'Higgins, M. Lago, \& T. H. DeWitt (Eds.), Ecosystem-based management, ecosystem services and aquatic biodiversity: Theory, tools and applications (pp. 417-430). Amsterdam: Springer.

National Academies of Sciences, Engineering, and Medicine (NASEM). (2006). Review of the marine recreational information program (MRIP). The National Academies Press, Washington, DC. https://doi.org/10.17226/24640. 
National Academies of Sciences, Engineering, and Medicine (NASEM). (2017). The science of science communication III: Inspiring novel collaborations and building capacity. Proceedings of a colloquium. The National Academies Press, Washington, DC. https://doi.org/10.17226/ 24958.

National Marine Sanctuaries. (2003). Strategic communication plan. Cordell Bank, Gulf of the Farallones, and Monterey Bay. pp 10. Retrieved October 20, 2019, from https://nmssanctuaries. blob.core.windows.net/sanctuaries-prod/media/archive/jointplan/cc_outreach/cc_nmsp_com_ temp.pdf.

National Oceanic and Atmospheric Administration (NOAA) Fisheries. (2016). NOAA Fisheries communications implementation plan for the Pacific Islands pp. 8. National Oceanic and Atmospheric Administration, National Marine Fisheries Services.

National Oceanic and Atmospheric Administration (NOAA) Office of Chief Information Officer. (2009). Communications plan: Reliable and consistent information exchange across NOAA's information technology community. pp. 21.

National Park Service (NPS). (2016). Wildland fire communication plan. Centennial edition: 2016-2020. pp. 18.

Newton, A., \& Elliott, M. (2016). A typology of stakeholders and guidelines for engagement in transdisciplinary, participatory processes. Frontiers in Marine Science, 3, 230.

O’Higgins, T., DeWitt, T. H., \& Lago, M. (2020). Using the concepts and tools of social ecological systems and ecosystem services to advance the practice of ecosystem-based management. In $\mathrm{T}$. O’Higgins, M. Lago, \& T. H. DeWitt (Eds.), Ecosystem-based management, ecosystem services and aquatic biodiversity: Theory, tools, and practice (pp. 3-14). Amsterdam: Springer.

Odugbemi, S., \& Mozammel, M. (2005). With the support of multitudes: Using strategic communication to fight poverty through PRSPs. London: World Bank Publications.

Okaka, W. (2010). Developing regional communications campaigns strategy for environment and natural resources management policy awareness for the east African community. Research Journal of Environmental and Earth Sciences, 2(2), 106-111.

Sea Grant. (2003). Positioning Sea Grant: An integrated national communications plan 2003-2006. pp. 24.

Sharpe, L., Hernandez, C., \& Jackson, C. (2020). Prioritizing stakeholders, beneficiaries and environmental attributes: A tool for ecosystem-based management. In T. O'Higgins, M. Lago, \& T. H. DeWitt (Eds.), Ecosystem-based management, ecosystem services and aquatic biodiversity: Theory, tools and applications (pp. 189-212). Amsterdam: Springer

Smith, D. C., Smith, A. D. M., Dichmont, C., Steele, W., \& Webb, H. (2014). Towards a strategic relationship between CSIRO and FRDC. Fisheries Research and Development Corporation, Australian Capital Territory.

Thompson, J. S. (2006). Strategic communication in community-based fisheries and forestry: A case from Cambodia. Ottawa: International Development Research Centre.

Timm, K., Hum, R., \& Duckenmiller, M. (2016). Using communication theory and strategy to communicate science and build stakeholder relationships in the Arctic. 2016 Arctic Observing Summit, Fairbanks, Alaska.

Turbek, S. P., Chock, T. M., Donahue, K., Havrilla, C. A., Oliverio, A. M., Polutchko, S. K., et al. (2016). Scientific writing made easy: A step-by-step guide to undergraduate writing in the biological sciences. Bulletin of the Ecological Society of America, 97(4), 417-426.

U.S. Fish and Wildlife Service (USFWS). (2011). North Atlantic LCC draft communications strategy, pp 14. Retrieved October 9, 2018, from https://www.fws.gov/northeast/science/pdf/ Handout_15_DRAFT_North_Atlantic_LCC_Comms_Plan_2011_0420.pdf.

U.S. Fish and Wildlife Service (USFWS). (2013). Desert Landscape Conservation Cooperative communications plan, pp 13. Retrieved October 20, 2019, from https://lccnetwork.org/resource/ desert-lcc-communications-plan.

U.S. Fish and Wildlife Service (USFWS). (2014) Climate change communications and engagement strategy for the National Wildlife Refuge System, pp 20. Retrieved October 20, 2019, from https://www.fws.gov/refuges/vision/pdfs/ClimateChangeEngagementStrategyFinal.pdf. 
U.S. Fish and Wildlife Service (USFWS). (2016). National Wildlife Refuge System Communications Strategy—Final, February 1, 2016, pp 25. Retrieved October 20, 2019, from https://www. fws.gov/refuges/vision/pdfs/NWRSCommunicationsStrategy.pdf.

Velasco, M. T. H. (2006). Management and implementation of communication programs for natural resources management in agriculture. In Food and Agricultural Organization (Ed.), Information and communication for natural resource management in agriculture: A training sourcebook (pp. 85-96). Los Banos: University of the Philippines.

Williams, K. C., \& Hoffman, J. C. (2020). Remediation to restoration to revitalisation: Ecosystembased management to support community engagement at clean-up sites in the Laurentian Great Lakes. In T. O’Higgins, M. Lago, \& T. H. DeWitt (Eds.), Ecosystem-based management, ecosystem services and aquatic biodiversity: Theory, tools and applications (pp. 543-560). Amsterdam: Springer

Winterfeldt, D. V. (2012). Bridging the gap between science and decision-making. The Proceedings of the National Academy of Sciences, 110(3), 14055-14061.

Yee, S., Cicchetti, G., DeWitt, T. H., Harwell, M. C., Jackson, S. K., Pryor, M., Rocha, K., Santavy, D. L., Sharpe, L., \& Shumchenia, E. (2020). The ecosystem services gradient: A descriptive model for identifying thresholds of meaningful change. In T. O'Higgins, M. Lago, \& T. H. DeWitt (Eds.), Ecosystem-based management, ecosystem services and aquatic biodiversity: Theory, tools and applications (pp. 291-308). Amsterdam: Springer.

Open Access This chapter is licensed under the terms of the Creative Commons Attribution 4.0 International License (http://creativecommons.org/licenses/by/4.0/), which permits use, sharing, adaptation, distribution and reproduction in any medium or format, as long as you give appropriate credit to the original author(s) and the source, provide a link to the Creative Commons licence and indicate if changes were made.

The images or other third party material in this chapter are included in the chapter's Creative Commons licence, unless indicated otherwise in a credit line to the material. If material is not included in the chapter's Creative Commons licence and your intended use is not permitted by statutory regulation or exceeds the permitted use, you will need to obtain permission directly from the copyright holder.

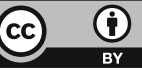

